\title{
Economic Integration and New Export Opportunities for the Eurasian Economic Union ${ }^{1}$
}

\author{
N. Volchkova, P. Kuznetsova, N. Turdyeva
}

\begin{abstract}
Natalya Volchkova - PhD in Economics, Professor, New Economic School, Policy Director, Centre for Economic and Financial Research; 47 Nakhimovsky Prospect, Office 720, 117418 Moscow, Russian Federation; E-mail: nvolchkova@cefir.ru
\end{abstract}

Polina Kuznetsova - Senior Economist, Centre for Economic and Financial Research; 47 Nakhimovsky Prospect, Office 720, 117418 Moscow, Russian Federation; E-mail: pkuznetsova@cefir.ru

Natalya Turdyeva - Senior Economist, Centre for Economic and Financial Research; 47 Nakhimovsky Prospect, Office 720, 117418 Moscow, Russian Federation; E-mail: nturdyeva@cefir.ru

At a time when oil prices are low, non-oil exports are important for the members of the Eurasian Economic Union $(E E U)$. This study assesses the effects of the EEU's economic integration on the development of new exports.

EEU countries are far behind global export leaders in several categories according to the revealed comparative advantage, used by the Hausmann-Klinger method to assess national export baskets. Belarus exports the most products, and Russia and especially Armenia and Kazakhstan export notably fewer.

The comparative advantages of Kazakhstan and Russia are concentrated mainly in minerals, chemical products and metals. The export structure for the other EEU countries is more diverse, with a high share of foodstuffs in Armenia and textiles in Belarus. Kazakhstan and, to a greater extent, Belarus and Russia show a rather complex export basket, significantly ahead of Armenia according to this indicator. For the EEU as an independent participant, its trade complexity index is higher than that for its member countries individually.

This article uses the Hausmann-Klinger methodology to identify the future comparative advantages of the EEU countries. These are product groups, towards which a structural transformation of the EEC exports most likely occurs. The research focuses on the integration aspect of possible non-oil exports, seeking to identify goods, including chemicals and textiles, that can eventually provide a comparative advantage for the EEU as a whole. Most of the products considered have a greater economic complexity than those in the EEU's current export basket, so would improve its overall export structure.

Key words: Eurasian Economic Union (EEU); trade integration; comparative advantage; Hausmann-Klinger methodology

\section{Introduction}

A clear understanding of the costs and benefits associated with regional trade and economic integration is essential to ensuring the sustainability of regional blocs. At the early stages of the creation of the Customs Union (CU) between Belarus, Kazakhstan and Russia, the economic

${ }^{1}$ This paper benefited from the research project TIGER (Trade Integration, Geopolitics and the Economy of Russia), Project No. 228244 funded by the Research Council of Norway (RCN) during 2013-2016 and coordinated by NUPI (Norwegian Institute of International Affairs), Oslo, Norway. Financial support from the RCN is gratefully acknowledged.

The article was submitted to the editors in April 2016. 
benefits of this enterprise were questioned, and they continue to be. For example, the main reason for doubt in Kazakhstan was the growth of its import tariffs after entry into the CU. In order to implement the Common Customs Tariff in the CU, Kazakhstan almost doubled its average tariff, from 5.3\% to $9.5 \%$ [Shepoltylo, 2011, p. 88] during the first year of its accession.

In 2015, the Customs Union was transformed into the Eurasian Economic Union (EAEU), and two new members joined it - Armenia and Kyrgyzstan. The new member states of the EAEU have prior international obligations as WTO members: Kyrgyzstan joined the WTO in 1998, and Armenia did so in 2001. In 2014, the simple average import tariff rate under the most favored nation status in Armenia was 3.7\%; in Kyrgyzstan this figure is 4.6\%. Due to differences between the obligations of Armenia and Kyrgyzstan to the WTO and the tariff schedules of the EAEU, these new members do not apply the full Common Customs Tariff of the EAEU. The accession of Armenia and Kyrgyzstan to the EAEU leads to numerous exceptions to the Common Customs Tariff. Additionally, these new EAEU member states started a procedure to correct their WTO obligations.

Despite the adverse effects of higher import prices being caused by the implementation of the Common Customs Tariff of the EAEU, Armenia and Kyrgyzstan stand to enjoy benefits that will compensate for the costs of being EAEU members. The importance of remittances from the countries of the EAEU to Kyrgyzstan and the benefits associated with the free movement of labor within the EAEU could eclipse the cost of increased import tariffs in terms of importance. Armenia also benefits from the free movement of labor, receiving Russian gas without export duties, and is interested in keeping the military guarantees provided by Russia through the Collective Security Treaty Organization.

In this period of high energy prices, the benefit to Belarus of participation in the CU was evident as high Russian export taxes on oil and gas were waived for it.

Within the framework of the EAEU, Kazakhstan's ambition is to be a safe haven for FDI in the production of goods and services for all five countries in the regional block.

The decrease of energy prices could significantly alter the balance of costs and benefits of being part of the EAEU for all five member states. In our opinion, it is important to understand whether there are other potential benefits (not mentioned above) to the deep integration of the five countries.

This study quantifies EAEU economic integration in terms of the development of new exports outside the Union. The benefits of the integration are defined as additional opportunities that the Union as a whole has in comparison with those of individual countries. We compare prospects for the non-oil exports of individual countries with the potential exports of the EAEU as an integrated single player in the global market for goods and services. The current state of the export basket of the EAEU is determined by summing up the exports of the member states to third countries and disregarding internal trade within the EAEU. The difference between the developed export opportunities of integrated associations and the total capacities of individual countries determines the potential benefits of the integration. It is worth mentioning that the importance of the new exports increases significantly when energy prices are low, and when other sources of benefits from regional integration that have been relevant in a time of high prices are exhausted.

The rest of the paper is organized as follows: in part 2 we describe the data; part 3 contains a description of the methodology; part 4 discusses the results, and is followed by a conclusion. 


\section{Data}

The following data are used in our calculations.

The UN COMTRADE database (2014) provides data on the value and volume of export flows from the EAEU member states to every country in the world using HS2012 6-digit classification http://comtrade.un.org/data/

The World Bank database contains data on GDP per capita and population figures http:// databank.worldbank.org/data/home.aspx

Due to the lack of data on Kyrgyzstan's exports in the COMTRADE database for 2014, it is excluded from the analysis. Thus, the calculations are carried out for four EAEU countries Armenia, Belarus, Kazakhstan and Russia.

\section{Methodology}

Our analysis of the prospects for the economic integration of the EAEU countries is carried out on the basis of the method proposed in a series of articles by Hausmann and Klinger [Hausmann, Klinger, 2006, 2007]. This method suggests a possible evolution of exports for each country. Usually, such evolution moves from technologically simple products, which are usually produced by poor countries, to more sophisticated products, which tend to be sold by rich countries. This process is called a structural transformation.

The method is based on a stylized fact consistently observed in empirical data: the structural transformation of national export baskets usually follows a certain pattern. The crucial observation is that over time, the country starts to export products, which are in some sense "close" to the basic products of the current export basket.

Hausmann and Klinger's notion of the proximity of goods is based on the concept of "product space" they proposed along with Cesar A. Hidalgo, and Albert-László Barabási in 2007 (see detailed description in [Hausmann et al., 2011, pp. 44-55], which attempts to visualize trade networks and spatially depict the comparative advantages and relatedness of products traded in the global market. The product space is a graph consisting of vertices (product groups) and edges whose length reflects the proximity of goods; related products requiring similar production capacity are depicted as being closer together and more central in the trade network.

The theoretical model estimates the profitability of a company from the new goods it produces. Switching to a new product is fundamentally different from the expansion of an existing product and involves certain costs. The costs of the structural transformation from one product to another depends on their relative proximity; in particular, on how the human capital of the employee applies in the new environment and how effective the producer is at re-purposing whatever was used in the production of the old goods.

The production of any good depends on such specific factors as human capital, fixed assets, intermediate goods, regulatory and infrastructure requirements, as well as ownership structure and other factors that are not always observable. The proximity of goods is determined by the aggregate proximity of factors required for their production. Since the space of factors is not always possible to specify explicitly, as not all of its components are observable and measurable, one can use the export basket of a country to guess to what extent it is supplied with all necessary factors. The logic behind this is the idea comes from the Heckscher-Ohlin model, where the comparative advantage of a country depends on factor abundance and demand for factors by production. 
As a measure of proximity of two products, Hausmann and Klinger suggest using the frequency of their simultaneous appearance as products of revealed comparative advantage (RCA) in the export baskets of various countries. Moreover, the proximity of goods empirically estimated with the procedure described above is interpreted as proximity of the production factors required for the effective production of these goods. Consequently, if there are some goods which are close to those contained in the export basket of a country and at the same time not contained in it themselves, one can expect that the probability of a structural transformation in the direction of these goods is higher than that it would be for the production of other, more 'distant' products.

The product space is not uniform; it has a densely filled central area where each commodity group has many close neighbors (i.e. many products in which direction a structural transformation is probable) and a much more sparse periphery, where the number of possible opportunities for expedient transformation is more limited.

The degree of proximity between goods reflects variation in specific factors of production, the speed of structural transformation depends on how sparse or, alternately, densely populated the product space is next to the existing country's revealed comparative advantage.

The density of the product space significantly influences the probability of the emergence of new comparative advantages. Some countries are in a sparse area of the product space, and some, on the contrary, in a much more densely-filled area. Structural transformation may slow down or stop in the event of a local price peak, when firms have no incentive to switch to the production of new goods, or if economically more advanced (and therefore more expensive) products are far away in the product space.

To formalize the model, Hausmann and Klinger introduce a few concepts. The presence of revealed comparative advantages in the country with exports of good $i$ at time $t$ is determined by the Balassa index. It is believed that there is a revealed comparative advantage, if the share of this product in country's exports ${ }^{x v a l} l_{c, i, t} / \sum_{i} x v a l_{c, i, t}$ exceeds the share of this product in global trade $\sum_{c} x v a l_{c, i, t} / \sum_{i} \sum_{c} x v a l_{c, i, t}$, i.e. the Balassa index is greater than 1.

In determining the affinity between any two commodities, Hausmann and Klinger assume that similar products are exported to most countries at the same time. The proximity between the goods $i$ and $j$ is defined as the smallest of the conditional probabilities of having a revealed comparative advantage in good $i$, if good $j$ is exported as well, and vice versa (RCA of good $j$, if good $i$ is exported as well):

$$
\phi_{i, j, t}=\min \left\{P\left(x_{i, t} \mid x_{j, t}\right), P\left(x_{j, t} \mid x_{i, t}\right)\right\},
$$

where $\mathrm{P}\left(\mathrm{x}_{\mathrm{i}, \mathrm{t}} \mid \mathrm{x}_{\mathrm{j}, \mathrm{t}}\right)$ - is the conditional probability of exporting good $i$, provided that good $j$ is exported at the time $t$. Conditional probabilities are calculated for all countries in year $t$ [Hausmann and Klinger, 2007, p. 16].

The measure of "price", reflecting the attractiveness of transition to the production of new good, is a measure of profitability of goods $i-$ PRODY $_{\mathrm{i}, \mathrm{t}}$. This measure was proposed in [Hausmann and Klinger, 2006, p. 17]. PRODY of good $i$ is defined as a weighted sum of GDP per capita in countries exporting good $i$, with weights equal to value of Balassa RCA of good $i$ : 


$$
\operatorname{PRODY}_{i, t}=\sum_{c}\left[\frac{\operatorname{xval}_{c, i, t} / \sum_{i} x v a l_{c, i, t}}{\sum_{c}\left(x v a l_{c, i, t} / \sum_{i} x v a l_{c, i, t}\right)} \times \text { GDPpercapita }_{c, t}\right]
$$

This measure is used to calculate the level of complexity of the country's export basket, EXPY $_{c, t}$, as the PRODY ${ }_{i, t}$ for each component of exports, weighted on its share in exports:

$$
E X P Y_{c, t}=\sum_{i}\left(\frac{x v a l_{c, i, t}}{\sum_{i} x v a l_{c, i, t}} \times P R O D Y_{i, t}\right)
$$

Hausmann and Klinger's methodology has been used in a variety of studies of countries' structural transformation of revealed comparative advantage with the help of historical data (see [Abdon and Felipe, 2011; Jankowska et al., 2012; Bayudan-Dacuycuy, 2012; Stafforte and Tamberi, 2012]).

There are also a number of studies that examines possible changes of RCA to product groups that are close to existing exports in a probabilistic sense. This transition is named diffusion of revealed comparative advantage (see [Hidalgo et al., 2007, pp. 5-6]).

In order to determine commodity groups, which could be the results of the diffusion process for the EAEU countries, it is necessary to study product groups that are close enough in the product space to the revealed comparative advantages of EAEU countries. To do this, we chose a proximity threshold of 0.7 and noted all the product groups, which are within this distance of the existing goods with RCA. It seems worth mentioning that this is a high level of proximity: as a rule, in other studies authors consider the values within the range $0.55-0.65$ as a threshold level (see [Hidalgo et al., 2011, p. 6; Bayudan-Dacuycuy, 2012, p. 4]). To account for the possible structural transformation of the country's exports, a similar procedure was carried out five times. We have also performed the sensitivity analysis of the results to the choice of the number of steps and the proximity threshold.

\section{Results of the Study}

Within our study (based on GDP per capita data and COMTRADE export data at the 6-digit product disaggregation for 2014) we consider two variants for the product space, a real-world one and a hypothetical one with the EAEU member countries combined into a single agent of world trade.

For real-world product space, we consider product groups with RCA for the EAEU member countries and with the help of the 5-step diffusion procedure define the groups where RCA could appear due to the structural transformation of national exports in the future.

Then the similar diffusion procedure is applied to the hypothetic product space, that occurs if the EAEU is considered as a single agent of foreign trade. Thus we obtain five sets of perspective goods: four sets for the countries included in the research (Armenia, Belarus, Kazakhstan, and Russia) and one for their hypothetical union (EAEU).

Finally we compare the prospective goods for the four national export baskets with those for the EAEU, focusing on those product groups that, while not offering RCA prospects for 
each separate country of the union, could benefit the EAEU in terms of their RCA as a single agent of foreign trade.

At the first step of our study, we identify product groups for which the EAEU countries had RCA in 2014, i.e. whose contribution to national exports was higher than the overall contribution of this product to global trade. According to the results obtained, the EAEU countries significantly lag the world export leaders in terms of the number of product groups with RCA. The largest number of products with comparative advantage is observed in the export basket of Belarus - 621 six-digit commodity groups, while in case of Russia and especially Armenia and Kazakhstan, this number is notably less - 377, 230 and 193 product groups respectively. As can be seen from the data presented in Table 1, the number of product groups with RCA in Armenia and Kazakhstan are almost an order of magnitude less than the respective figures for such world trade leaders as China and the United States.

To get some insight about the economic complexity of the national export baskets of the EAEU countries, one can use EXPY, the index of the sophistication of exports (see the definition in the Methodology section). Our estimates suggest that Belarus, Kazakhstan and Russia demonstrate relatively high values of economic complexity of national export baskets, significantly ahead of Armenia in this indicator. In the case of international comparisons, the complexity of the exports of the EAEU countries is close to China's level (around USD 20,000$22,000)$, albeit far behind the successful exporters of high-tech products, specifically the USA (over USD 26,000).

It is also worth mentioning that the complexity level of exports of the EAEU as an independent market engaged in foreign trade is higher than that of the separate member countries. This indicates that the EAEU members' exports to third countries are more sophisticated than exports within the Union's borders.

Table 1: Characteristics of products with revealed comparative advantage for the EAEU member countries, China and the US

\begin{tabular}{|l|c|c|c|c|c|c|c|}
\hline \multicolumn{1}{|c|}{ Index } & Armenia & Belarus & Kazakhstan & Russia & EAEU & China & USA \\
\hline $\begin{array}{l}\text { Number of product } \\
\text { groups with revealed } \\
\text { comparative advantage } \\
\text { (RCA) }\end{array}$ & 230 & 621 & 193 & 377 & 325 & 2196 & 1749 \\
\hline $\begin{array}{l}\text { Export complexity } \\
\text { (EXPY), USD }\end{array}$ & 12345 & 20217 & 19383 & 21296 & 22625 & 22720 & 26560 \\
\hline
\end{tabular}

Source: Authors' calculations on UN COMTRADE data.

If we talk about the involvement of member countries in trade within the EAEU, the country which is most dependent on its partners' markets is Belarus, with $45 \%$ of its exports sent to EAEU countries (primarily Russia). Armenia sends $22 \%$ of its exports to its EAEU partners. The exports of oil-producing Kazakhstan and Russia are much more likely to be sent to countries outside the EAEU; these countries' trade with other EAEU members accounted only for $8 \%$ and $7 \%$ of exports, respectively.

With regard to the range of export baskets of the member countries, it may be noted that almost a third of all 6-digit commodities exported from Belarus are completely targeted at the EAEU countries. For other member countries, the share of goods traded exclusively within the union is lower, about $10 \%$ for Russia and Armenia, and 22\% for Kazakhstan. Over $80 \%$ of the types of products Belarus exports are sent to fellow EAEU states more often than not (for these 
products, $50 \%+$ of exports are to EAEU members). More than $55 \%$ of the types of products Russia exports are primarily sent to its EAEU partners. Some integration figures are shown in Table 2.

Table 2: Indicators of economic integration within the EAEU

\begin{tabular}{|l|c|c|c|}
\hline \multicolumn{1}{|c|}{ Country } & $\begin{array}{c}\text { The share of trade within the } \\
\text { union in total exports, \% }\end{array}$ & $\begin{array}{c}\text { The share of goods } \\
\text { exported only to EAEU } \\
\text { countries EAEU, \% }\end{array}$ & $\begin{array}{c}\text { The share of export goods } \\
\text { predominantly (50\%+) } \\
\text { bought within the EAEU, } \\
\%\end{array}$ \\
\hline Armenia & 22 & 10 & 23 \\
\hline Belarus & 45 & 31 & 81 \\
\hline Kazakhstan & 8 & 22 & 49 \\
\hline Russia & 7 & 10 & 56 \\
\hline
\end{tabular}

Source: Authors' calculations on UN COMTRADE data.

\section{Products with Revealed Comparative Advantage}

An analysis of the sectoral structure of comparative advantages suggests that Kazakhstan and Russia's export benefits are concentrated mainly in the production of mineral and chemical products as well as metals, while the RCA structure of other member countries is more diverse, with a high share of food products in Armenia and textiles in Belarus (Fig. 1). It should also be noted that Belarus has more goods with revealed comparative advantage in the group "machinery and electronics" (about 80 product groups).

For the EAEU as a consolidated participant in global trade (net of internal trade flows between the countries of the union), the sectoral distribution of RCA reflects those of Russia and Kazakhstan, with a predominance of metal production as well as chemical and mineral products.

Furthermore, we estimate how close, or, alternately, how far the effective part of the export basket of the EAEU countries is from the rest of the commodities (we call the product groups without RCA the "opportunity set"). In other words, we try to understand the likelihood of the structural transformation of exports from current goods with RCA towards those that are currently not produced efficiently. This can be done using the indicator "the distance to the current export basket", which is calculated as the inverse of average proximity between a product from the opportunity set and all existing products with RCA. This indicator measures how close in terms of the Hausmann-Klinger method products are from the opportunity set to the current effective part of the national export basket.

The diagram below presents the opportunity spaces for each of the four countries included in the research (Fig. 2). For each product group from the opportunity set, the dependence is shown between the distance to the most effective part of the country's export basket and the relative complexity of this product (the complexity is defined as the logarithm of the product complexity index (PRODY), normalized to the value of the total complexity of the effective part of the national export basket (EXPY)). Thus, more complicated products (whose complexity is greater than the average complexity of the effective part of the national export basket) are located above zero on the vertical axis. In terms of another variable, distance, the closer the goods are to the vertical axis, the more likely it is to expect their appearance as a commodity of comparative advantage in the export basket of the country. 


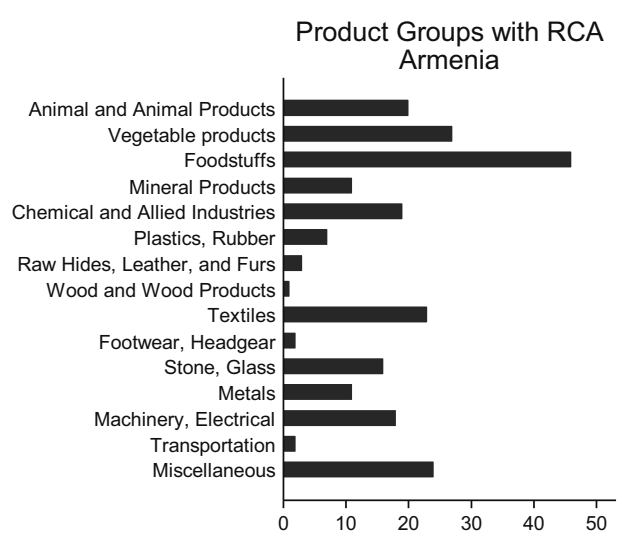

Product Groups with RCA Kazakhstan

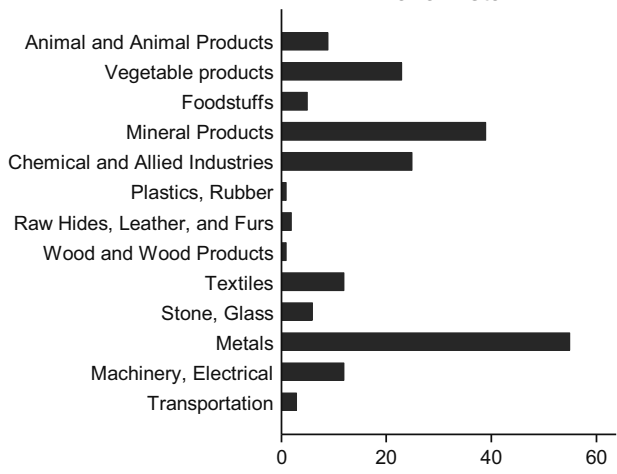

Product Groups with RCA EAEU

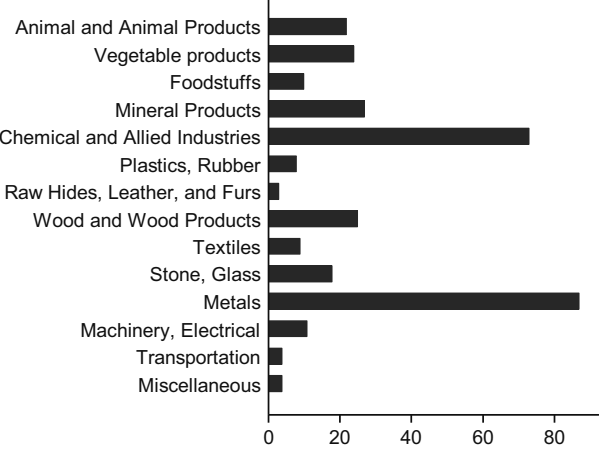

Product Groups with RCA Belarus

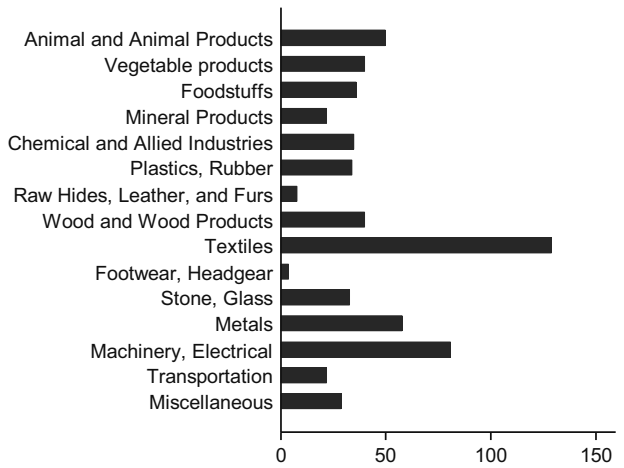

Product Groups with RCA Russia

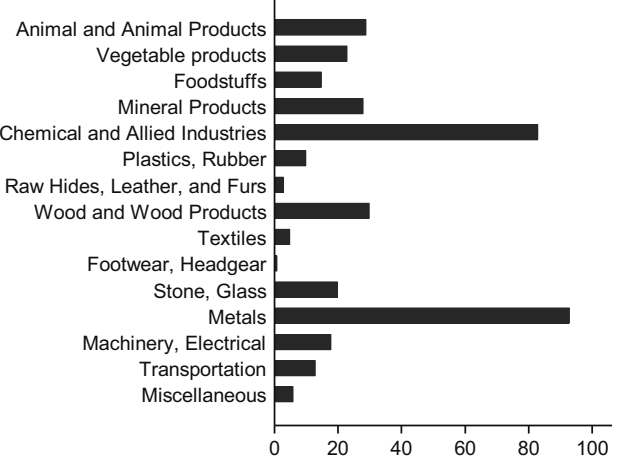

Figure 1: Product groups with revealed comparative advantage (RCA) for the member countries and the EAEU as a single agent of foreign trade

Source: Authors' calculations on UN COMTRADE data.

Among the countries of the EAEU, the closest distance from the opportunity set of products to the most effective part of the actual export basket is observed for Belarus (6.0). For Russia, Armenia and especially Kazakhstan, this distance is significantly higher: 12.7, 14.1 and 
24.3, respectively. Thus, we can conclude that the high diversification of the export basket of Belarus, as well as the favorable location of its RCA groups in the central, densely filled part of the product space, facilitates the future structural transformation of the country's exports in comparison with Armenia and Russia. At the same time, the prospects of a successful structural transformation of Kazakhstan's export are small. It is also worth mentioning that some upward shift of the opportunity set for Armenia reflects the relatively lower complexity of the current effective part of the national export basket.

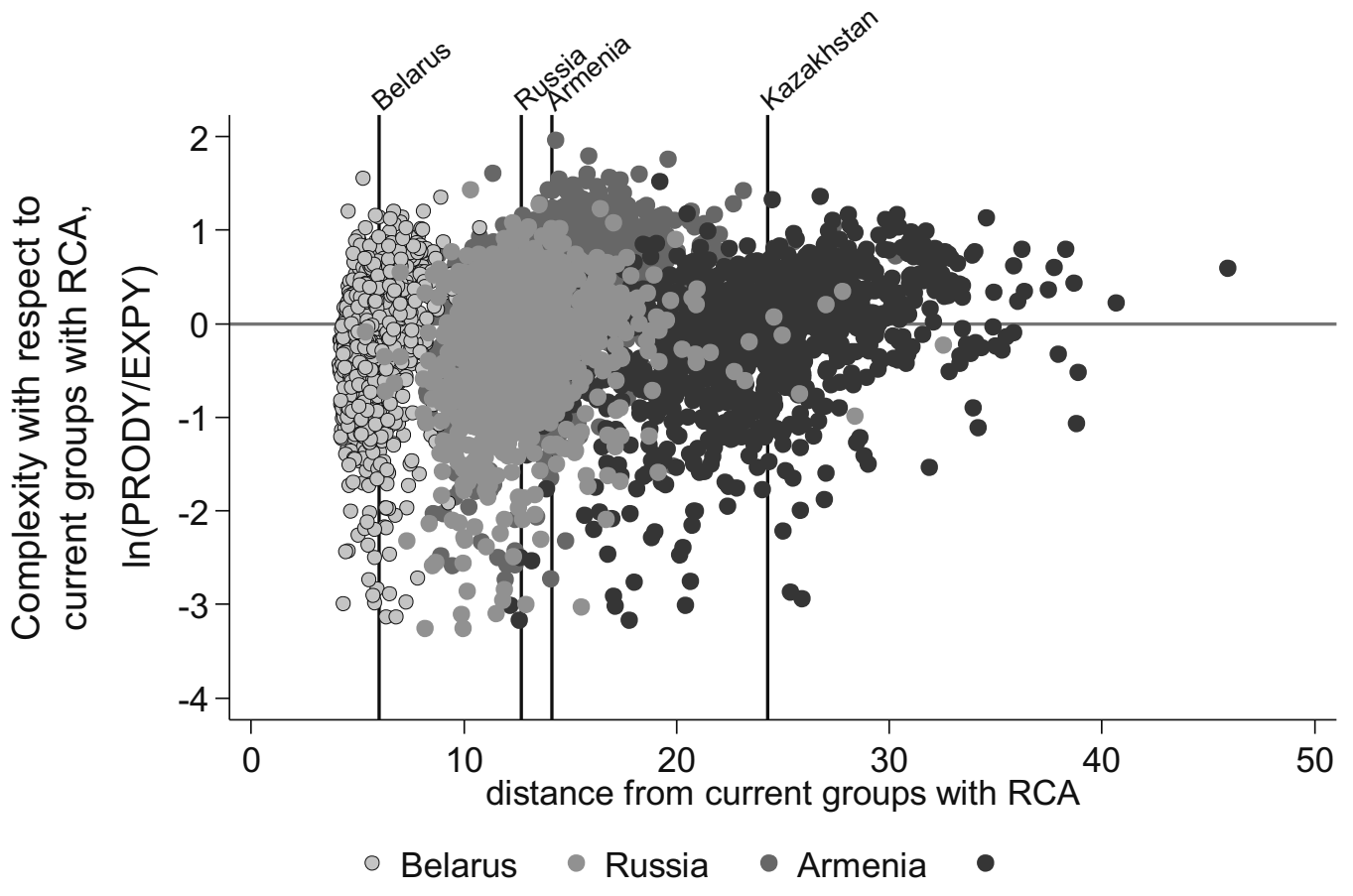

Figure 2: The relative complexity of the goods without RCA, depending on the measure of the probability of their appearance in the effective part of the national export basket for EAEU countries, 2014

Source: Authors' calculations on UN COMTRADE data.

\section{Expected Groups with RCA}

During the analysis for each country we generate a list of product groups which are close to the current products and possess revealed comparative advantage (we also call them expected product groups with RCA). These items were defined with the help of a 5-step diffusion procedure with a proximity threshold equal 0.7 at each step. The probability of appearance in the export basket of new products with revealed comparative advantage depends on how easily the country's current capacity can be adapted to the production of new goods. Most expected products for Armenia and Belarus can be categorized as light industry, and Russia's production capacity could allow it to excel in the chemical industry as well as the production of plastics and metals (Fig. 3). Note that the number of such groups for Kazakhstan is significantly less (9 as compared to 97 for Armenia, 137 for Belarus, and 111 for Russia), and their relationship with current products with RCA is weaker. This can be explained by the fact that current goods with RCA 
in the export basket of Kazakhstan belong to the minerals and metals group, and are mainly located on the periphery of the product space, where the density of groups falls significantly.

With regard to the EAEU's prospects as a consolidated participant in global trade, the sectoral structure of the expected product groups with RCA resembles Russia, as in the case of current products with RCA. However, there would be a EAEU predominance of chemical products and markedly lower share of plastics and machinery products; one notable exception is that the expected RCA of light industry would grow significantly. One can assume that it is due to a large density within the textile and clothing cluster of the product space, which includes many products from the effective parts of the Armenian and Belorussian export baskets.

In order to evaluate the effect of economic integration in the sectoral structure of expected groups with RCA for the EAEU as a consolidated participant in global trade, we have focused on the products that are not expected products with RCA for any of the EAEU countries separately.

Figure 4 shows the distribution of products, from the perspective of the EAEU as a consolidated participant of foreign trade. The white areas of the bars on the chart correspond to the groups whose transition to the status of the products with RCA is expected for the union as a whole, the green - only for Belarus, the blue - only for Russia and the dark blue - for several countries within the EAEU. The most interesting, in terms of cooperation, are white areas corresponding to the 6-digit commodity groups. There you find anticipated products with RCA only for the EAEU in general, and not for any of the member countries separately.

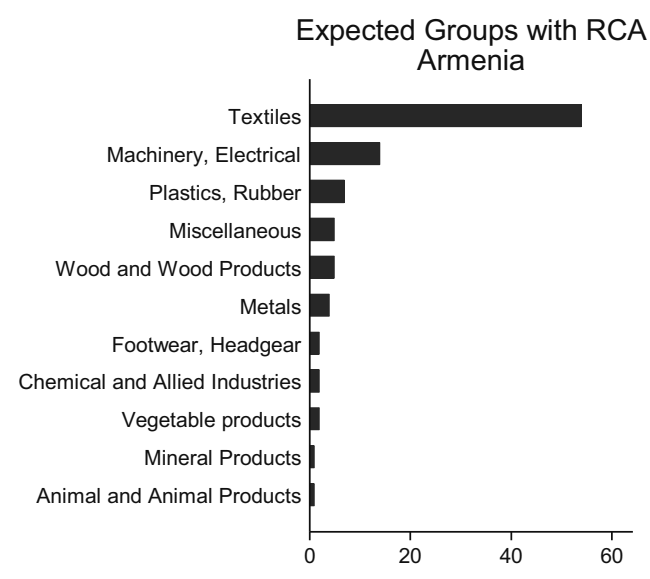

Expected Groups with RCA Kazakhstan

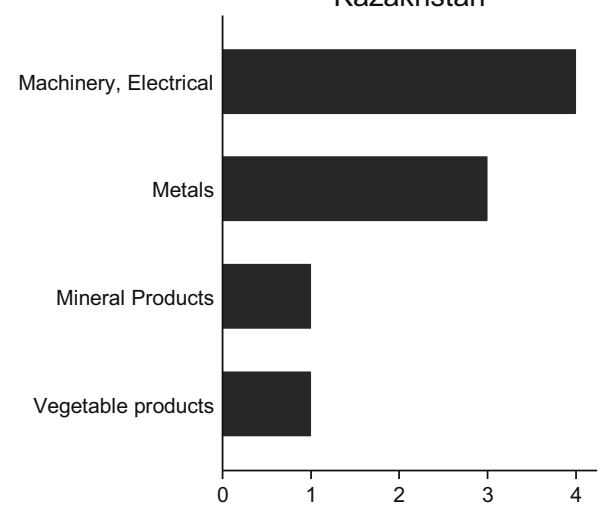

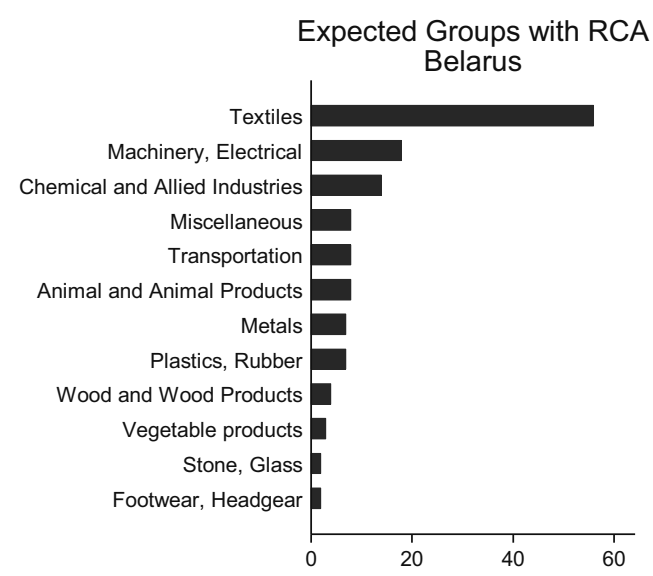

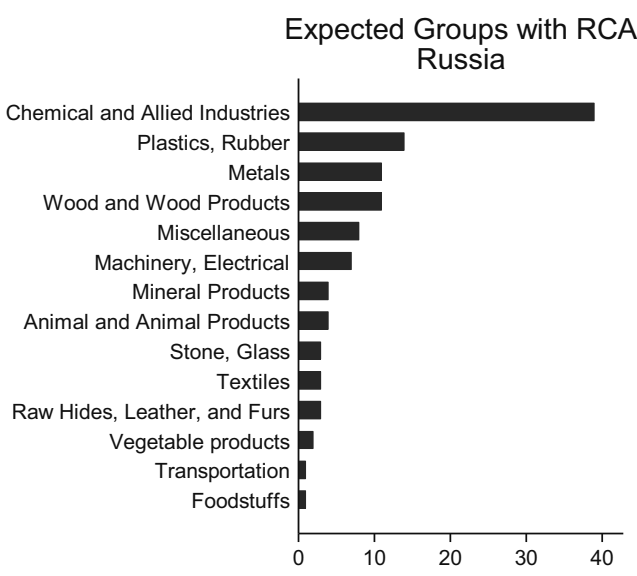




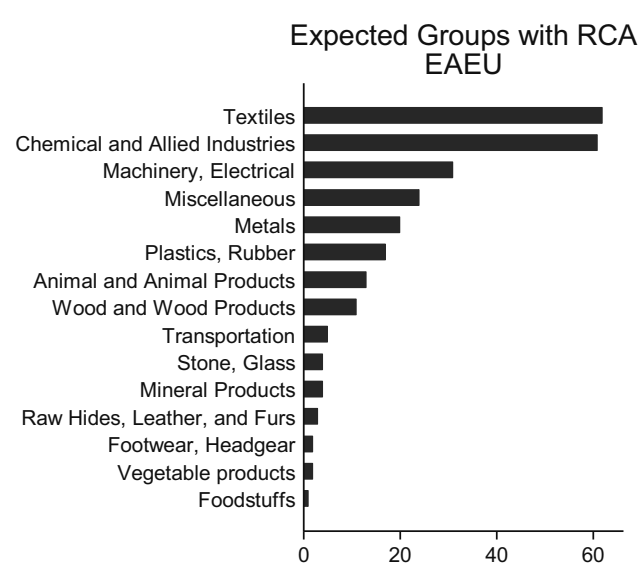

Figure 3: Sectoral structure of prospective product groups for EAEU countries' exports

Source: Authors' calculations on UN COMTRADE data.

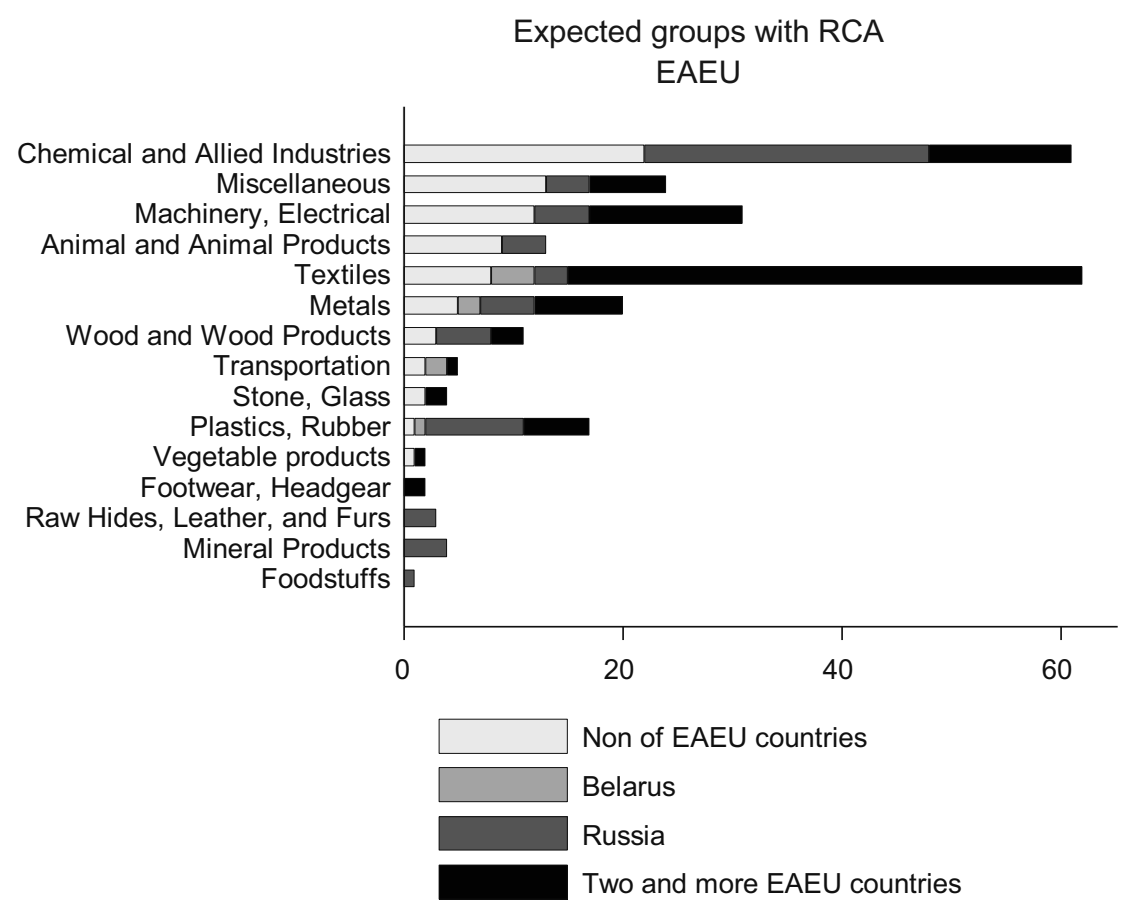

Figure 4: The sectoral structure of expected groups with RCA for the EAEU as a consolidated participant in foreign trade

Source: Authors' calculations on UN COMTRADE data.

The total number of expected product groups with RCA is 78. Most often they are related to chemicals (22 products), other products (13 products), as well as machinery and engineering (12 items). Most of these products (62 out of 78) have greater economic complexity than the average complexity of the export basket of the EAEU, and therefore their export growth will 
improve the overall export structure. Groups of goods selected by the diffusion procedure are presented in the table below (Table 3).

Table 3: Expected product groups with RCA only for the EAEU as a whole (i.e., that are not expected for any of the EAEU countries individually)

\begin{tabular}{|c|c|c|c|c|c|}
\hline Field & $\begin{array}{c}\text { HS4 } \\
\text { (2012) }\end{array}$ & & $\begin{array}{c}\text { Balassa } \\
\text { index }\end{array}$ & PRODY & $\begin{array}{l}\text { World trade, bln } \\
\text { USD, } 2014\end{array}$ \\
\hline $\begin{array}{l}\text { Wood and Wood } \\
\text { Products }\end{array}$ & 481830 & $\begin{array}{l}\text { Tablecloths and serviettes, of paper pulp, paper, } \\
\text { cellulose wadding or webs of cellulose fiber }\end{array}$ & 0.0153 & 19026 & 1.21 \\
\hline $\begin{array}{l}\text { Wood and Wood } \\
\text { Products }\end{array}$ & 482040 & $\begin{array}{l}\text { Manifold business forms and interleaved carbon } \\
\text { sets made of paper or paperboard; albums for } \\
\text { samples or for collections and book covers made } \\
\text { of paper or paperboard }\end{array}$ & 0.0207 & 19026 & 0.11 \\
\hline $\begin{array}{l}\text { Wood and Wood } \\
\text { Products }\end{array}$ & 440890 & $\begin{array}{l}\text { Other articles of wood, sawn lengthwise, sliced } \\
\text { or peeled, of a thickness not exceeding } 6 \mathrm{~mm} \text {, } \\
\text { including planed, sanded, spliced and end-jointed }\end{array}$ & 0.4020 & 19026 & 1.86 \\
\hline $\begin{array}{l}\text { Animal and } \\
\text { Animal Products }\end{array}$ & 30473 & Frozen fillets of pollock (Pollachius virens) & 0.0092 & 19026 & 0.18 \\
\hline $\begin{array}{l}\text { Animal and } \\
\text { Animal Products }\end{array}$ & 30561 & $\begin{array}{l}\text { Herrings (Clupea harengus, Clupea pallasii), } \\
\text { salted but not dried or smoked and fish in brine, } \\
\text { other than edible fish offal }\end{array}$ & 0.9429 & 19026 & 0.03 \\
\hline $\begin{array}{l}\text { Animal and } \\
\text { Animal Products }\end{array}$ & 20311 & Pork, fresh or chilled, carcasses and half-carcasses & 0.0000 & 19026 & 2.63 \\
\hline $\begin{array}{l}\text { Animal and } \\
\text { Animal Products }\end{array}$ & 30224 & $\begin{array}{l}\text { Flat fish Turbots (Psetta maxima, } \\
\text { Scophthalmidae), fresh or chilled, excluding fish } \\
\text { fillets and other fish meat of heading }\end{array}$ & 0.0015 & 19026 & 0.13 \\
\hline $\begin{array}{l}\text { Animal and } \\
\text { Animal Products }\end{array}$ & 40310 & $\begin{array}{l}\text { Yogurt, including concentrated, containing added } \\
\text { sugar or other sweeteners as well as flavored or } \\
\text { containing added fruit, nuts or cocoa }\end{array}$ & 0.1384 & 19026 & 2.35 \\
\hline Stone, Glass & 700800 & Multiple-walled insulating units of glass & 0.0283 & 19026 & 1.56 \\
\hline Stone, Glass & 711011 & Platinum, unwrought or in powder form & 0.1450 & 19026 & 8.83 \\
\hline $\begin{array}{l}\text { Machinery, } \\
\text { Electrical }\end{array}$ & 846711 & $\begin{array}{l}\text { Hand tools, pneumatic tools, and rotary-type } \\
\text { tools (including combined rotary-percussion) }\end{array}$ & 0.0295 & 19026 & 0.9 \\
\hline $\begin{array}{l}\text { Machinery, } \\
\text { Electrical }\end{array}$ & 851521 & $\begin{array}{l}\text { Machines and apparatuses for the resistance } \\
\text { welding of metal, fully or partly automatic }\end{array}$ & 0.0455 & 19026 & 1.88 \\
\hline $\begin{array}{l}\text { Machinery, } \\
\text { Electrical }\end{array}$ & 847981 & $\begin{array}{l}\text { Other machines and mechanical appliances, for } \\
\text { treating metal, including electric wire coil-winders }\end{array}$ & 0.1195 & 19026 & 1.76 \\
\hline $\begin{array}{l}\text { Machinery, } \\
\text { Electrical }\end{array}$ & 850730 & $\begin{array}{l}\text { Electric accumulators, as well as separators, } \\
\text { whether or not rectangular (including square), } \\
\text { nickel-cadmium }\end{array}$ & 0.2099 & 19026 & 0.96 \\
\hline $\begin{array}{l}\text { Machinery, } \\
\text { Electrical }\end{array}$ & 844530 & Textile doubling or twisting machines & 0.0019 & 19026 & 0.23 \\
\hline $\begin{array}{l}\text { Machinery, } \\
\text { Electrical }\end{array}$ & 846593 & Grinding, sanding or polishing machines & 0,0268 & 19026 & 0,29 \\
\hline $\begin{array}{l}\text { Machinery, } \\
\text { Electrical }\end{array}$ & 842129 & $\begin{array}{l}\text { Other filtering or purifying machinery and } \\
\text { apparatuses for liquids }\end{array}$ & 0,0665 & 19026 & 8,57 \\
\hline $\begin{array}{l}\text { Machinery, } \\
\text { Electrical }\end{array}$ & 842420 & Spray guns and similar appliances & 0,0197 & 19026 & 1,71 \\
\hline $\begin{array}{l}\text { Machinery, } \\
\text { Electrical }\end{array}$ & 844842 & $\begin{array}{l}\text { Reeds for weaving machines (looms), heddles and } \\
\text { heddle-frames }\end{array}$ & 0.0343 & 19026 & 0,06 \\
\hline
\end{tabular}




\begin{tabular}{|c|c|c|c|c|c|}
\hline Field & $\begin{array}{c}\text { HS4 } \\
(2012)\end{array}$ & & $\begin{array}{l}\text { Balassa } \\
\text { index }\end{array}$ & PRODY & $\begin{array}{l}\text { World trade, bln } \\
\text { USD, } 2014\end{array}$ \\
\hline $\begin{array}{l}\text { Machinery, } \\
\text { Electrical }\end{array}$ & 840310 & Central heating boilers & 0.0425 & 19026 & 5.09 \\
\hline $\begin{array}{l}\text { Machinery, } \\
\text { Electrical }\end{array}$ & 841360 & $\begin{array}{l}\text { Other rotary positive displacement pumps for } \\
\text { liquids, whether or not fitted with a measuring } \\
\text { device }\end{array}$ & 0.0808 & 19026 & 6.35 \\
\hline $\begin{array}{l}\text { Machinery, } \\
\text { Electrical }\end{array}$ & 842511 & $\begin{array}{l}\text { Pulley tackle and hoists other than skip hoists or } \\
\text { hoists of a kind used for raising vehicles, powered } \\
\text { by electric motors }\end{array}$ & 0.0392 & 19026 & 1 \\
\hline Metals & 741011 & $\begin{array}{l}\text { Foil (whether or not printed or backed with paper, } \\
\text { paperboard, plastics or similar backing materials) } \\
\text { of a thickness not exceeding } 0.15 \mathrm{~mm} \text {, of refined } \\
\text { copper }\end{array}$ & 0.0574 & 19026 & 1.45 \\
\hline Metals & 722100 & $\begin{array}{l}\text { Bars and rods, hot-rolled, in irregularly wound } \\
\text { coils, of stainless steel. }\end{array}$ & 0.0005 & 19026 & 1.9 \\
\hline Metals & 722720 & $\begin{array}{l}\text { Bars and rods, hot-rolled, in irregularly wound } \\
\text { coils, of silico-manganese steel }\end{array}$ & 0.5832 & 19026 & 0.44 \\
\hline Metals & 721250 & $\begin{array}{l}\text { Flat-rolled products of iron or non-alloy steel, of } \\
\text { a width of less than } 600 \mathrm{~mm} \text {, otherwise plated or } \\
\text { coated }\end{array}$ & 0.0013 & 19026 & 0.57 \\
\hline Metals & 820340 & $\begin{array}{l}\text { Pipe-cutters, bolt croppers, perforating punches } \\
\text { and similar tools }\end{array}$ & 0.0097 & 19026 & 0.18 \\
\hline Plastics, Rubbers & 390740 & Polycarbonates & 0.0577 & 19026 & 7.75 \\
\hline $\begin{array}{l}\text { Vegetable } \\
\text { products }\end{array}$ & 120510 & Low erucic acid rape or colza seeds & 0.3277 & 19026 & 10 \\
\hline Miscellaneous & 900319 & $\begin{array}{l}\text { Frames and mountings for spectacles, goggles or } \\
\text { the like, and parts thereof, of other materials }\end{array}$ & 0.0032 & 19026 & 2.03 \\
\hline Miscellaneous & 902720 & Chromatographs and electrophoresis instruments & 0.0141 & 19026 & 1.84 \\
\hline Miscellaneous & 950440 & Table or parlor games: playing cards & 0.0018 & 19026 & 0.76 \\
\hline Miscellaneous & 900653 & Other cameras, for $35 \mathrm{~mm}$ roll film & 0.0112 & 19026 & 0.06 \\
\hline Miscellaneous & 901850 & Other ophthalmic instruments and appliances & 0.0317 & 19026 & 4.03 \\
\hline Miscellaneous & 902990 & $\begin{array}{l}\text { Revolution counters, production counters, } \\
\text { taximeters, mileometers, pedometers and the like; } \\
\text { speed indicators and tachometers; stroboscopes: } \\
\text { parts and accessories }\end{array}$ & 0.0303 & 19026 & 1.54 \\
\hline Miscellaneous & 902519 & $\begin{array}{l}\text { Thermometers and pyrometers, not combined } \\
\text { with other instruments, other }\end{array}$ & 0.0718 & 19026 & 2.4 \\
\hline Miscellaneous & 902230 & X-ray tubes & 0.2294 & 19026 & 1,57 \\
\hline Miscellaneous & 903082 & $\begin{array}{l}\text { Other instruments and apparatuses for measuring } \\
\text { or checking semiconductor wafers or devices }\end{array}$ & 0.0007 & 19026 & 3.09 \\
\hline Miscellaneous & 901390 & $\begin{array}{l}\text { Parts and accessories for liquid crystal devices; } \\
\text { lasers, other than laser diodes; other optical } \\
\text { appliances and instruments }\end{array}$ & 0.1101 & 19026 & 5.76 \\
\hline Miscellaneous & 940600 & Prefabricated buildings & 0.2133 & 19026 & 8.98 \\
\hline Miscellaneous & 950639 & Golf clubs and other golf equipment & 0.0000 & 19026 & 1.11 \\
\hline Miscellaneous & 940360 & Other wooden furniture & 0.0844 & 19026 & 26.22 \\
\hline Textiles & 540744 & $\begin{array}{l}\text { Other printed woven fabrics, containing } 85 \% \\
\text { or more by weight of filaments of nylon or other } \\
\text { polyamides }\end{array}$ & 0.3462 & 19026 & 0.15 \\
\hline
\end{tabular}




\begin{tabular}{|c|c|c|c|c|c|}
\hline Field & $\begin{array}{c}\text { HS4 } \\
(2012)\end{array}$ & & $\begin{array}{l}\text { Balassa } \\
\text { index }\end{array}$ & PRODY & $\begin{array}{l}\text { World trade, bln } \\
\text { USD, } 2014\end{array}$ \\
\hline Textiles & 610451 & $\begin{array}{l}\text { Women's or girls' skirts and divided skirts of wool } \\
\text { or fine animal hair }\end{array}$ & 0.0080 & 19026 & 0.05 \\
\hline Textiles & 630259 & Other table linen of other textile materials & 0.8066 & 19026 & 0.14 \\
\hline Textiles & 551642 & $\begin{array}{l}\text { Dyed woven fabrics of artificial staple fiber, } \\
\text { containing less than } 85 \% \text { by weight of artificial } \\
\text { staple fiber, mixed mainly or solely with cotton }\end{array}$ & 0.0009 & 19026 & 0.06 \\
\hline Textiles & 620312 & Men's or boys' suits of synthetic fiber & 0.0075 & 19026 & 0.77 \\
\hline Textiles & 620899 & $\begin{array}{l}\text { Women's or girls' other clothing articles of other } \\
\text { textile materials }\end{array}$ & 0.0182 & 19026 & 0.2 \\
\hline Textiles & 620590 & Men's or boys' shirts of other textile materials & 0.0048 & 19026 & 0.74 \\
\hline Textiles & 610690 & $\begin{array}{l}\text { Women's or girls' blouses, shirts and shirt-blouses, } \\
\text { knitted or crocheted of other textile materials }\end{array}$ & 0.0042 & 19026 & 0.52 \\
\hline Transportation & 871639 & $\begin{array}{l}\text { Other trailers and semi-trailers for the transport of } \\
\text { goods: other }\end{array}$ & 0.1039 & 19026 & 8.86 \\
\hline Transportation & 860730 & $\begin{array}{l}\text { Hooks and other coupling devices, buffers, } \\
\text { and parts thereof for of railway or tramway } \\
\text { locomotives or rolling-stock }\end{array}$ & 0.3129 & 19026 & 0.85 \\
\hline $\begin{array}{l}\text { Chemical and } \\
\text { Allied Industries }\end{array}$ & 381511 & $\begin{array}{l}\text { Supported catalysts with nickel or nickel } \\
\text { compounds as the active substance }\end{array}$ & 0.0012 & 19026 & 1.07 \\
\hline $\begin{array}{l}\text { Chemical and } \\
\text { Allied Industries }\end{array}$ & 381519 & Other supported catalysts & 0.3505 & 19026 & 4.4 \\
\hline $\begin{array}{l}\text { Chemical and } \\
\text { Allied Industries }\end{array}$ & 292219 & $\begin{array}{l}\text { Other amino-alcohols, other than those } \\
\text { containing more than one kind of oxygen } \\
\text { function, their ethers and esters; salts thereof }\end{array}$ & 0.0987 & 19026 & 2.28 \\
\hline $\begin{array}{l}\text { Chemical and } \\
\text { Allied Industries }\end{array}$ & 291229 & $\begin{array}{l}\text { Other cyclic aldehydes without other oxygen } \\
\text { functions }\end{array}$ & 0.0000 & 19026 & 0.45 \\
\hline $\begin{array}{l}\text { Chemical and } \\
\text { Allied Industries }\end{array}$ & 292149 & $\begin{array}{l}\text { Other aromatic monoamines and their derivatives; } \\
\text { salts thereof }\end{array}$ & 0.0001 & 19026 & 1.04 \\
\hline $\begin{array}{l}\text { Chemical and } \\
\text { Allied Industries }\end{array}$ & 382430 & $\begin{array}{l}\text { Non-agglomerated metal carbides mixed together } \\
\text { or with metallic binders }\end{array}$ & 0.0142 & 19026 & 0.7 \\
\hline $\begin{array}{l}\text { Chemical and } \\
\text { Allied Industries }\end{array}$ & 293321 & Hydantoin and its derivatives & 0.0000 & 19026 & 0.17 \\
\hline $\begin{array}{l}\text { Chemical and } \\
\text { Allied Industries }\end{array}$ & 291429 & $\begin{array}{l}\text { Other cyclanic, cyclenic or cycloterpenic ketones } \\
\text { without other oxygen function }\end{array}$ & 0.0005 & 19026 & 0.82 \\
\hline $\begin{array}{l}\text { Chemical and } \\
\text { Allied Industries }\end{array}$ & 290539 & Other diols & 0.0000 & 19026 & 1.72 \\
\hline $\begin{array}{l}\text { Chemical and } \\
\text { Allied Industries }\end{array}$ & 292529 & Other imines and their derivatives; salts thereof & 0.1325 & 19026 & 0.73 \\
\hline $\begin{array}{l}\text { Chemical and } \\
\text { Allied Industries }\end{array}$ & 290522 & Acyclic terpene alcohols & 0.0017 & 19026 & 0.26 \\
\hline $\begin{array}{l}\text { Chemical and } \\
\text { Allied Industries }\end{array}$ & 291639 & $\begin{array}{l}\text { Other aromatic monocarboxylic acids, their } \\
\text { anhydrides, halides, peroxides, peroxyacids and } \\
\text { their derivatives }\end{array}$ & 0.0002 & 19026 & 0.72 \\
\hline $\begin{array}{l}\text { Chemical and } \\
\text { Allied Industries }\end{array}$ & 292990 & Other compounds with other nitrogen function & 0.1182 & 19026 & 0.62 \\
\hline $\begin{array}{l}\text { Chemical and } \\
\text { Allied Industries }\end{array}$ & 290920 & $\begin{array}{l}\text { Cyclanic, cyclenic or cycloterpenic ethers and } \\
\text { their halogenated, sulphonated, nitrated or } \\
\text { nitrosated derivatives }\end{array}$ & 0.0003 & 19026 & 0.08 \\
\hline
\end{tabular}




\begin{tabular}{|c|c|c|c|c|c|}
\hline Field & $\begin{array}{l}\text { HS4 } \\
(2012)\end{array}$ & & $\begin{array}{c}\text { Balassa } \\
\text { index }\end{array}$ & PRODY & $\begin{array}{l}\text { World trade, bln } \\
\text { USD, } 2014\end{array}$ \\
\hline $\begin{array}{l}\text { Chemical and } \\
\text { Allied Industries }\end{array}$ & 291469 & Other quinones & 0.0003 & 19026 & 0.4 \\
\hline $\begin{array}{l}\text { Chemical and } \\
\text { Allied Industries }\end{array}$ & 293369 & $\begin{array}{l}\text { Other compounds containing an unfused triazine } \\
\text { ring (whether or not hydrogenated) in the } \\
\text { structure }\end{array}$ & 0.3902 & 19026 & 1.54 \\
\hline $\begin{array}{l}\text { Chemical and } \\
\text { Allied Industries }\end{array}$ & 290899 & $\begin{array}{l}\text { Other halogenated, sulphonated, nitrated or } \\
\text { nitrosated derivatives of phenols or phenol- } \\
\text { alcohols }\end{array}$ & 0.0013 & 19026 & 0.12 \\
\hline $\begin{array}{l}\text { Chemical and } \\
\text { Allied Industries }\end{array}$ & 290329 & $\begin{array}{l}\text { Other unsaturated chlorinated derivatives of } \\
\text { acyclic hydrocarbons }\end{array}$ & 0.0000 & 19026 & 0.12 \\
\hline $\begin{array}{l}\text { Chemical and } \\
\text { Allied Industries }\end{array}$ & 291539 & Other esters of acetic acid & 0.0865 & 19026 & 1.55 \\
\hline $\begin{array}{l}\text { Chemical and } \\
\text { Allied Industries }\end{array}$ & 330290 & $\begin{array}{l}\text { Other preparations based on odoriferous } \\
\text { substances, of a kind used for the manufacture of } \\
\text { beverages }\end{array}$ & 0.0077 & 19026 & 7.82 \\
\hline $\begin{array}{l}\text { Chemical and } \\
\text { Allied Industries }\end{array}$ & 291100 & $\begin{array}{l}\text { Acetals and hemiacetals, whether or not with } \\
\text { other oxygen functions, and their halogenated, } \\
\text { sulphonated, nitrated or nitrosated derivatives }\end{array}$ & 0.0020 & 19026 & 0.11 \\
\hline $\begin{array}{l}\text { Chemical and } \\
\text { Allied Industries }\end{array}$ & 291823 & Other esters of salicylic acid and their salts & 0.0001 & 19026 & 0.21 \\
\hline
\end{tabular}

Note. ${ }^{*}-2015$, exports of this group has increased significantly, reaching USD $2 \mathrm{mln}$ (for comparison, in 2014 - USD 5,000)

Source: Authors' calculations on UN COMTRADE data.

\section{Conclusion}

According to the results of our research, the EAEU member countries are far behind the world export leaders in terms of number of product groups with revealed comparative advantage (RCA), which within the Hausmann-Klinger method are interpreted as the most effective part of the national export basket. The largest number of products with comparative advantage is observed in the export basket of Belarus, while in the case of Russia and especially Armenia and Kazakhstan, their number is notably less (however, it must be kept in mind that over $4 / 5$ of the products Belarus exports are shipped predominantly (50\% and more) to Russia). The export baskets of Belarus and Russia are highly complex, as measured by the EXPY (export sophistication) index, followed by Kazakhstan, which, in turn, is significantly ahead of Armenia in terms of this indicator. EAEUIf seen as a consolidated participant in global trade, the EAEU's complexity index is higher than that of member countries separately. The comparative advantages of exports from Kazakhstan and Russia are concentrated mainly in the production of minerals, chemical products, and metals, while the export structure of the effective part of exports for other member countries is more diverse, with a high share of foodstuffs in Armenia and textiles in Belarus.

Within the analysis we defined a list of product groups, within which one can expect the occurrence of revealed comparative advantage in the future. According to the results, groups in Armenia and Belarus groups which should expect RCA are mostly related to light industry, and Russia should expect RCA from chemical production and related industries. For Kazakhstan, the number of potential comparative advantages is much smaller due to the peculiarities of the sectoral structure of the current effective part of the national export basket: these goods (mainly 
minerals and metals) are located on the periphery of the world product space, where the density of the product groups significantly drops, casting doubt on the success of structural transformation in the future.

In the sectoral structure of the EAEU as a consolidated participant in foreign trade, chemical products and light industry products stand to offer the best RCA. The marked increase in the importance of textiles and clothing for the EAEU can be attributed to the development of this sector in Armenia and Belarus, as well as the high density of the textile cluster in the world product space, where the current products with RCA are located in the tight environment of other product groups in the sector.

To estimate the possible effect of economic integration within the EAEU, one must consider commodities that are not promising in terms of comparative advantage for any of the EAEU countries individually, but are nonetheless promising for the EAEU as a consolidated participant in global trade. According to our calculations, most often such goods belong to the chemical industry (22 products), other products (13 products), as well as machinery and engineering (12 items). Most of these products (62 out of 78) have greater economic complexity than that of the current EAEU export basket, so one can assume that their export growth will improve the overall export structure of the EAEU countries.

\section{References}

Abdon A., Felipe J. (2011) The Product Space: What Does it Say About the Opportunities for Growth and Structural Transformation of Sub-Saharan Africa? Levy Economics Institute Working Papers, no 670. Available at: http://dx.doi.org/10.2139/ssrn.1846734 (accessed 08 November 2016).

Bayudan-Dacuycuy C. (2012) The Philippine export portfolio in the product space: potentials, possibilities and policy challenges. Economics Bulletin, AccessEcon, vol. 32(1), pp. 59-66.

Hausmann R., Hidalgo C., Bustos S., Coscia M., Chung S., Jimenez J., Simoes A., Yildirim M. (2011) The Atlas of Economic Complexity. Cambridge M.A.: Center for International Development, Harvard University.

Hausmann R., Hwang J., Rodrik D. (2007) What You Export Matters. Journal of Economic Growth, no (12) 1, pp. $1-15$.

Hausmann R., Klinger B. (2006) Structural Transformation and Patterns of Comparative Advantage in the Product Space. CID Working Paper, no 128.

Hausmann R., Klinger B. (2007) The Structure of the Product Space and the Evolution of Comparative Advantage. CID Working Paper, no 146.

Hidalgo C., Klinger B., Barabasi A.-L., Hausmann R. (2007) The Product Space Conditions: the Development of Nations. Science, vol. 317, no 5837, pp. 482-487.

Jankowska A., Nagengast A., Perea J.R. (2012) The Product Space and the Middle-Income Trap: Comparing Asian and Latin American Experiences. OECD Development Centre Working Papers, no 311. OECD Publishing, Paris. Available at: http://dx.doi.org/10.1787/5k9909j2587g-en (accessed 08 November 2016).

Stafforte S., Tamberi M. (2012) Italy in the Space (of products) [Italia nello spazio (dei prodotti)]. Economia Marche/Journal of Applied Economics, vol. 0 (1), pp. 90-113.

World Bank (2012) Assessment of Costs and Benefits of the Customs Union for Kazakhstan. First Report under the Study of International Practice of Integration/Customs Unions, 3 January. Washington DC: World Bank. Available at: http://documents.worldbank.org/curated/en/190711468041116333/Assessment-of-costs-andbenefits-of-the-customs-union-for-Kazakhstan (accessed 08 November 2016). 